09,30

Evaluación de sistemas curriculares y percepción del estrés en estudiantes de Medicina en las Universidades de Santiago de Chile y Austral de Chile Huaquin, V., Loaiza, R., Altamirano P., Sanhueza, C Universidad Austral de Chile y Universidad de Santiago de Chile

\section{9,40}

Expectativas estudiantiles sobre exigencias académicas implicantes de estrés curricular en la carrera de Medicina

Sanhueza C., Loaiza R., Huaquín V., y Altamirano P. Universidad Austral de Chile

\section{9,50}

Los valores en la Educación Médica

Marta Durán Escribano

Universidad de Alcalá

\section{0,00}

La necesidad de evaluar la calidad de los artículos sobre intervenciones educativas

Ruiz de Gauna P., Fonseca M., Arana Erri E., Meana J.J.,

Pineda J., Fermoso J. Uriarte T., Alfonso M., Salcedo F., Asua J. y Gutiérrez-Ibarzulea I.

Grupo de Trabajo Proyecto FISS de Evaluación de Tecnologías Sanitarias. Depto. de Neurociencias. Facultad de Medicina. Universidad del País Vasco

\section{0,10}

Búsqueda de la evidencia sobre proyectos curriculares basados en competencias finales

Gutiérrez-Ibarzulea I., Fonseca M., Arana Erri E., Meana, J.J., Ruiz de Gauna P., Pineda J., Fermoso J., Uriarte T. Alfonso M., Salcedo F., Asua J.

Grupo de Trabajo Proyecto FISS de Evaluación de Tecnologías Sanitarias. Depto. de Neurociencias. Facultad de Medicina. Universidad del País Vasco

10,20

Discusión

\section{comunicaciones en forma de panel}

53 Viernes 24 de octubre $18 \mathrm{~h}$

Sesión PA (P1-P10) Aula Pittaluga

1. The role of the teacher in medical education: the Medical School of Porto University teacher profile ${ }^{1}$

Ferreira A.F., Crosby J. Soares I, Tavares M.A.

Gabinete de Educação Médica da Faculdade de Medicina do Porto (Gem-FMUP)

2. Aportes de las propuestas de formación docente a la calidad de la educación médica Candreva A., Susacasa S.

Facultad Ciencias Médicas. Universidad Nacional de La Plata. Argentina.

3. "Puente Iberoamericano" para la formación continua de docentes de áreas biomédicas Lafuente, JV., Escanero JF, Gargiulo P, Mora S., Gorena D. y Manso JM.

Universidad del País Vasco, U. de Zaragoza, U. Ncal. de Cuyo, U. de Chile, U. Andina Simón Bolivar, U. de Valladolid

4. Autoevaluación de la titulación de Medicina de la Universidad de Las Palmas de Gran Canaria Freixinet J., Rodríguez de Castro F., Fanjul L.F, Cabrera J. Facultad de medicina. Universidad de Las Palmas de Gran Canaria
5. Valoración de la titulación de Medicina por los alumnos Freixinet J.,Rodríguez de Castro F., Fiuza *MD., Castro JL..Cabrera P., Cabrera J.

Facultad de Medicina. Universidad de Las Palmas de Gran Canaria. Unidad de Investigación. Hospital Universitario de Gran Canaria Dr. Negrín *

6. Autoevaluación de la Facultad de Medicina de Málaga. Análisis de los resultados de los alumnos

Pérez de Vargas I; Ruiz-Cruces R., Cabello MR., Villena, A. Pena J.M.

Facultad de Medicina. Universidad de Málaga

7. Los alumnos de la Facultad de Medicina de la Universidad de Barcelona opinan sobre las asignaturas del plan de estudios

Vallès A., Cerrilo E., Crespí J., Fernández S., Ginés A., Girbau M., Grados D., Marota A., Mestres J., Molina A., Vique C. Facultat de Medicina de la Universitat de Barcelona

8. Actitudes de los alumnos de la licenciatura de medicina frente a la docencia de Fisiología en el nuevo plan de estudios Quesada T. Fenoy, F., Hernández I., Salom G., Serna*A.,

Carbonell, L.F.

Departamento de Fisiología Humana. Facultad de Medicina."

Servicio de Informática(ATICA). Universidad de Murcia

9. Evaluación de las competencias clínicas en las Facultades de Medicina de Catalunya, 2002 Kronfly E., Gràcia L., Julià X., Majó J., Prat J., Castro A., Bosch JA., Urrutia A. Gineno JL., Blay C., Pujol R., Martínez-Carretero JM. Institut d'Estudis de la Salut. Barcelona

10. Evaluación de la formación enfermera

Rojas P., Armero D., González A., Ruzafa M., Sánchez J.A., Muñoz G. Departamento de Enfermería. Universidad de Murcia.

Sesión PB (P11-P20) Salón de Actos 11. Importancia de los alumnos internos en el Departamento de Anatomía y Embriología Humana Miguel, M., Porta N., Ortiz J., De Anta J., Lorente M., Götzens V. Departamento de Anatomía y Embriología Humana. Facultad de Medicina. (Campus de Bellvitge) Universidad de Barcelona

12. El trabajo colaborativo a través del foro virtual Torres B. ${ }^{1}$, Vallès A. ${ }^{2}$

Dpto. Anatomía Humana ${ }^{1}$ Dpto. Salud Pública ${ }^{2}$. Facultat de Medicina. Universitat Barcelona

13. How to promote integration between Anatomy and Radiology in medical education: IMAN2003 as an educational interface

Tavares MAF ${ }^{1,2}$, Loureiro, E. ${ }^{2}$, Dinis-Machado J. ${ }^{1}$, Pinto P. ${ }^{3}$, Ramos I. ${ }^{3}$

${ }^{1}$ Institute of Anatomy, ${ }^{2}$ Office of Medical Education and

${ }^{3}$ Radiology and Medical Image Service, FMUP/HSJ. Porto, Portugal

14. Protección radiológica en Medicina. Situación actual de la docencia de pregrado

${ }^{1}$ Ruiz-Cruces R.,${ }^{2}$ Vañó E. ${ }^{3}$ Hernández-Armas J. ${ }^{2}$ Gonzalez L., ${ }^{1}$ Diez de los Ríos A.

Departamentos de Radiología de las Universidades de ${ }^{1}$ Málaga, ${ }^{2}$ Complutense $y{ }^{3}$ La Laguna

15. Propuesta de programa básico sobre protección radiológica en el curriculum de las facultades de medicina

${ }^{2}$ Gonzalez L. ${ }^{1}$ Ruiz-Cruces R., ${ }^{2}$ Vañó,E. ${ }^{3}$ Hernández-Armas J.

${ }^{4}$ Galvez M., ${ }^{5}$ Peña JJ. ${ }^{6}$ Arranz L.

Universidades ${ }^{1}$ Complutense, ${ }^{2}$ Málaga, ${ }^{3}$ La Laguna, ${ }^{4}$ Córdoba, ${ }^{5}$ Extremadura $y{ }^{6}$ Hospital Ramón y Cajal de Madrid 
16. Semiología radiológica de aparato digestivo: un CD-ROM interactivo

${ }^{1}$ Alcaraz M., ${ }^{1}$ Chico P., ${ }^{2}$ Armero D., y ${ }^{1}$ Saura Iniesta A. M. $\mathrm{y}{ }^{3}$ Vicente V.

${ }^{1}$ Área de Radiología y Medicina Física y ${ }^{2}$ Área de Enfermería, ${ }^{3}$ Área de Anatomía Patológica, Facultad de Medicina,

Universidad de Murcia, 30100-Espinardo. España

17. Detección de errores conceptuales en Biologia ( $1^{\circ}$ y $2^{\circ}$ curso de Medicina)

García de Galdeano, A., Cañabate ML., Alvarez, A., Arlucea, I., Hilario E.

Dpto. de Biología Celular e Histología. Facultad de Medicina y Odontología Universidad del País Vasco

18. A plurilevel approach to study skills in the Medical School course.

Bastos A. ${ }^{1,2}$, Tavares M.A.F. ${ }^{1}$

${ }^{1}$ Office of Medical Education, FMUP and ${ }^{2}$ School of Education, Polytechnic Institute of Viana do Castelo. Portugal

19. "How to prepare and succed in the exams": A course on study skills in the Faculty of Medicine of Porto Loureiro E. ${ }^{1}$, Martins M.J. ${ }^{1,2}$, Neves D. ${ }^{3}$, Tavares M.A. ${ }^{1,4}$, Bastos A. ${ }^{1,3}$ Office of Medical Education ', Department of Biochemistry ${ }^{2}$, Department of Molecular and Cellular Biology ${ }^{3}$, Institute of Anatomy, FMUPP', School of Education, Polytechnic Institute of Viana do Castelo, Portugal

20. Utilidad del problema como intrumento de integración vertical

Escanero, JF., Guerra, M., Alda, JO., Gambarte, AJ.*

Departament de Farmacología y Fisiología Univ. de Zaragoza, España. * Facultad de Ciencias Médicas Univ. Nacional de Cuyo, Mendoza Argentina

Sesión PC (P21-P29) Aula 1

21. ¿Cómo aprenden los estudiantes universitarios?. Estudio comparativo entre las titulaciones de Medicina y Magisterio

Díez M., Compañ A.F., Soriano A., Candela A., Bernabeu M., Pérez - Vázquez M.T., Medrano J.

Departamento de Patología y Cirugía. Universidad Miguel Hernández

22. ¿Cómo prefieren aprender los estudiantes universitarios en la era del espacio europeo de educación superior? Díez M., Compañ A.F., Candela A., Bernabeu M.,

Pérez-Vázquez M.T., Lacueva F.J., Medrano J.

Departamento de Patología y Cirugía. Universidad Miguel Hernández

23. Mobility programs in the Faculty of Medicine of the University of Porto (FMUP) as a tool to improve quality in medical education

Gramaxo $\mathrm{S}^{1}$, Loureiro E ${ }^{1}$, Bastos A. ${ }^{1}$, Ferreira $\mathrm{C}^{2}$, Tavares M.A.F. ${ }^{1}$

${ }^{1}$ Office of Medical Education, International Office, FMUP;

${ }^{2}$ University of Porto.

24. Programa de tutorización de alumnos visitantes en la Facultad de Medicina de Málaga

Cabello MR., Ruiz-Cruces R., Villena A., Pérez de Vargas I.

Facultad de Medicina. Universidad de Málaga.

25. Evaluación de la movilidad estudiantil en la Facultad de Medicina de Málaga

Cabello MR., Ruiz-Cruces R. Villena A., Pérez de Vargas I.

Facultad de Medicina. Universidad de Málaga

26. ¿Cómo andamos de créditos europeos?.

El estado de la cuestión en la Facultad de Ciencias de la Salud y de la Vida de la Universidad Pompeu Fabra Pérez J., Aquizu N., Caracuel L., Carreño C., Dalmases A., Diz A. Facultad de Ciencias de la Salud y de la Vida. UPF
27. ¿Cómo andamos de créditos europeos?. El estado de la cuestión en la Facultad de Psicologia de la Universidad de Santiago de Compostela

Pérez J. ${ }^{1}$ Carrillo-de-la-Peña M.T. ${ }^{2}$, Bellas V. ${ }^{2}$; Parada M. ${ }^{2}$,

Pascual S. ${ }^{2}$, Piñeiro B. ${ }^{2}$, Rey B. ${ }^{2}$, Rodríguez L. ${ }^{2}$, Sanromán D. ${ }^{2}$,

Torres S. ${ }^{2}$, Vázquez L. ${ }^{2}$

${ }^{1}$ Facultad de Ciencias de la Salud y de la Vida. UPF.

${ }^{2}$ Facultad de Psicología. USC.

28. ¿Cómo andamos de créditos europeos?. El estado de la cuestión en la Facultad de Medicina de la Universidad de Barcelona

Vallès A., Fernández de Sevilla, M., Salvador R., Algans E., Miró M., Salvador F., Canals M., Vendrell A., Pujol A. García A. Facultat de Medicina de la Universitat de Barcelona

29. Adaptación de la Licenciatura de Medicina al espacio europeo de educación superior

Pérez de Vargas I., Ruiz-Cruces R. Cabello MR. Villena A., Parrado C., González-Barón S.

Facultad de Medicina. Universidad de Málaga

Sesión PD (P30-P42) Aula 2

30. Percepción de profesionales/alumnos acerca del diploma en docencia en Ciencias de la Salud Castillo M., Miranda T., López I., González X.,Velasco C. Universidad de Chile

31. Promoción de la formación médica continuada de los estudiantes de medicina mediante resolución de un tema de investigación

Chung C., Gutierrez M $\mathrm{M}^{\mathrm{a}}$ y Gómez R.

Departamento de Obstetricia y Ginecología,

Facultad de Medicina, Universidad de Granada

32. Relación entre percepción del entorno académico y estado de salud mental: análisis multifactorial, 1999-2003 Benassi L., López Ma del R., Poveda J., Pastor V., Santa-Maria, A., Rodríguez Fernández $\mathrm{M}^{\mathrm{a}}$. I.

Facultad de Medicina. U.A.M. Madrid. España

33. ¿Es diferente la evaluación de médicos y enfermeras sobre curso básico interprofesional en cuidados paliativos para la atención primaria?

Nogueras A., Grimau I., Ruiz M., Martínez M.

Cuidados paliativos. Hospital de Sabadell. Institut Universitari Parc Tauli (UAB)

34. Proceso de la acreditación y reacreditación de tutores de residentes de Medicina Familiar y Comunitaria de Valencia Gutiérrez M $M^{\mathrm{a}}$ D., Gosalbes V., Fernández C., Gil F., Albert X. Unidad Docente de Medicina Familiar y Comunitaria de Valencia

35. ¿Qué opinan los médicos residentes de Medicina de Familia y Comunitaria de los cursos recibidos durante su periodo formación?

Leiva F., Carrión MT., Prados JD.

Unidad Docente de Medicina de Familia y Comunitaria.

Hospital Civil. Málaga

36. Evaluación de la formación docente de postgrado en el Hospital Universitario Ntra. Sra. de Candelaria Hernández M. A., Marco Ma . T., Porta E. Sangüesa,

R. Hernández R.

Comisión de Docencia. Hospital Universitario

Ntra. Sra. de Candelaria. Sta. Cruz de Tenerife

37. Validez y confiabilidad de OSCE en postgrado Miranda T., Gasic M., Salas J., Mandiola E., Castillo M., Velasco $\mathrm{C}$.

Universidad de Chile 
38. ¿Estrés y cansancio inciden en rendimiento en OSCE? Miranda T., Gasic M., Salas J., Mandiola E., Castillo M., Velasco C.

Universidad de Chile

39. Estímulo a la evaluación metacognitiva Miranda T., Castillo M., González X., Mandiola E., López I., Velasco C.

Universidad de Chile

40. Formación dirigida a promover la inserción laboral de médicos

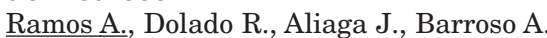

Centro de Estudios Colegiales del Colegio Oficial de Médicos de Barcelona

41. Valoración de un cuestionario de detección de necesidades de formación para médicos

Ramos A., Barroso T., Aliaga J.

Colegio Oficial de Médicos de Barcelona

42. Descripción del curso de perfeccionamiento para la obtención del Título de Especialista en Medicina Familiar y Comunitaria

Arranz JM., Martínez, JM.

Institut d'Estudis de la Salut (IES). Barcelona
43. Método informatizado de formación médica Juanes JA ${ }^{1}$; Velasco MA²; Mirón JA ${ }^{3}$; Cabrero FJ

Rodríguez-Conde $\mathrm{MJ}^{5}$,Prats $\mathrm{A}^{6}$, de Lagándara, $\mathrm{ML}^{7}$, Goya, $\mathrm{R}$

${ }_{1,3,4}^{4}$ Facultad de Medicina. Universidad de Salamanca.

${ }^{2}$ Centro de Salud "Miguel Armijo". Salamanca,

${ }^{5}$ Facultad de Educación. Universidad de Salamanca,

${ }^{6}$ Facultad de Medicina. Universidad de Barcelona,

${ }^{7}$ Abadía. Desarrollos informáticos. Madrid.

44. Visualización volumétrica animada de estructuras cerebrales con fines docentes

Juanes JA ${ }^{1}$; Prats A ${ }^{2}$, de Lagándara, $\mathrm{ML}^{3}$, Mirón JA ${ }^{1}$;

Cabrero $\mathrm{FJ}^{1}$; Rodríguez-Conde $\mathrm{MJ}^{4}$

${ }^{1}$ Facultad de Medicina. Universidad de Salamanca.

${ }^{2}$ Facultad de Medicina. Universidad de Barcelona.

${ }^{3}$ Grupo ABADÍA. Desarrollos Informáticos. Madrid.

${ }^{4}$ Facultad de Educación. Universidad de Salamanca. 


\title{
XVI Congreso Nacional de la Sociedad Española de Educación Médica
}

\author{
Madrid, 22-25 de octubre de 2003
}

\section{Comité de Honor}

Excma. Sra. Ministra de Sanidad y Consumo. Doña. Ana María Pastor Julián.

Excmo. Sr. Secretario de Estado de Educación y Universidades.

D. Julio Iglesias de Ussel.

Excmo. Sr. Dirección General de Recursos Humanos y Servicios Económico-presupuestarios D. Jaume Aubia Marimón.

Excmo. Sr. Alcalde del Ayuntamiento de Madrid. D. Alberto Ruiz-Gallardón

Ilmo. Sr. Presidente de la Real Academia Nacional de Medicina.

D. Amador Schüller Pérez

Excmo. y Magfco. Sr. Rector Magnífico de la Universidad de Alcalá de Henares

D. Virgilio Zapatero Gómez

Excmo. y Magfco Sr. Rector Magnífico de la Universidad Autonoma de Madrid.

D. Ángel Gabilondo Pujol

Excmo. Sr. Vicerrector de Ordenación Académica y planes de estudio de la Universidad rey Juan Carlos

D. Eduardo García Poblete

Ilmo. Sr. Presidente del Consejo General de Colegios Oficiales de Médicos.

D. Guillermo Sierra Arredondo

Ilmo. Sr. Presidente del Consejo General de Colegios Oficiales de Farmacéuticos.

D. Pedro Capilla Martínez

Ilmo. Sr. Presidente del Consejo General de Colegios Oficiales de Enfermería

D. Máximo A. González Jurado

Junta Directiva de SEDEM

Presidente: Prof. Dr. Jorge L. Palés Argullós

Vicepresidentes:

Prof. Dr. José Ma Manso Martínez.

Prof. Dr. Jesús Escanero Marcén

Vicepresidenta institucional:

Prof. Dr. José Ignacio Paz Bouza

Secretario-Tesorero (e.f.):

Prof. Dr. Arcadi Gual Sala

Vicesecretaria: Dra. Maria Nolla Domenjó

Vocales: Prof. Dr. Vicente Pastor Aldeguer

Prof. Dr. José Ma Peinado Herreros

Prof. Dr. Felipe Rodríguez de Castro

Prof. Dr. Juan Viñas Salas

Vocalias institucionales:

Prof. Dr. Jesús Escanero Marcén (SADEM)

Profa. Dra. Montserrat Fonseca Alfonso

(SEMDE)

Dr. Ramón Pujol Farriols (ACEM)
Comité Organizador

Presidente: Prof. Dr. Antonio Campos Muñoz

Vicepresidentas:

Profa. Dra. Nelly García-López Hernández.

Profa. Dra. M ${ }^{a}$ Dolores Serrat Moré

Vocales: $\mathrm{D}^{\mathrm{a}}$ Mercedes Alastruey Cuesta

$\mathrm{D}^{\mathrm{a}}$ Aurora de Elías Doral

$\mathrm{D}^{\mathrm{a}} \mathrm{M}^{\mathrm{a}}$ José Fraile Soria

Dra. M ${ }^{a}$ José Medrano Albero

Dr. Miguel Angel Royo Bordonada

Prof. Dr. José Ignacio Paz Bouza

$\mathrm{D}^{\mathrm{a}}$ Rosana Sanjuán Fernández

Dr. Jorge Veiga de Cabo

Secretario: Prof. Dr. Arcadi Gual Sala

\section{Comité Científico}

Presidente: Dr. Manuel Carrasco Mallén

Vicepresidentes:

Prof. Dr. Felipe Rodríguez de Castro

Dr. Jorge Veiga de Cabo

Vocales: Dra. M ${ }^{\mathrm{a}}$ Teresa Alfonso Roca

Prof. Dr. Jesús F. Escanero Marcén

Prof. Dra. Rosa Fenoll Brunet

Dr. José $\mathrm{M}^{\mathrm{a}}$ Fornells Vallés

Dra. Maria Nolla Domenjó

Prof. Dr. Vicente Pastor Aldeguer

Prof. Dr. José $\mathrm{M}^{\mathrm{a}}$ Peinado Herreros

Prof. Dr. Joan Prat Corominas

Secretario: Prof. Dr. Arcadi Gual Sala

\section{Organiza}

- Instituto de Salud Carlos III. Subdirección General de Formación y Difusión de la Investigación Sanitaria - SEDEM

\section{Colabora}

- Agencia Laín Entralgo. Comunidad de Madrid

- Conferencia Nacional de Decanos de Facultades

de Medicina Españolas

- IES

- Institue for International Medical Education

- Fundación Educación Médica

- Fundación Medicina y Humanidades Médicas

- Fundación: Salud Innovación Sociedad

- SEMFyC 


\section{Congreso Nacional de la Sociedad Española de Educación Médica (SEDEM)}

Fiel a su cita bienal, la Sociedad Española de Educación Médica convoca a todos los educadores de las ciencias de la salud de nuestro país a su Congreso Nacional, en su decimosexta edición. En esta ocasión quiero destacar que, por primera vez en sus 33 años de historia, la SEDEM celebra su congreso en un marco distinto al de una Facultad de Medicina.

La SEDEM, a lo largo de su historia, ha celebrado siempre sus congresos en una Facultad de Medicina, en las cuales siempre se ha sentido acogida. Ello es lógico habida cuenta que la Sociedad se fundó en una institución universitaria, que sus fundadores eran fundamentalmente profesores de universidad, que un gran número de sus socios son profesores y que siempre, como en esta ocasión, se ha tenido el inestimable apoyo de la Conferencia Nacional de Decanos de Facultades de Medicina Españolas.

En los últimos diez años se han sucedido importantes cambios en las estructuras de los sistemas sanitarios y la SEDEM, sensible a estos procesos, se ha acercado progresivamente al mundo de las profesiones sanitarias, en todas sus etapas, formación de pregrado, formación de postgrado y el desarrollo profesional continuo o formación continuada. En este sentido, un factor facilitador del acercamiento a otros ámbitos diferentes del pregrado fue la firma en el año 2001 de un convenio marco de colaboración entre la SEDEM y el Instituto de Salud Carlos III. Este convenio estimulaba la celebración de actividades conjuntas, entre las que cabe destacar los Cursos de Formación de Profesorado de las Licenciaturas y Diplomaturas en Ciencias de la Salud y Cursos de Formación de Tutores en Postgrado, organizados por el Departamento de Metodología Docente y Gestión de la Educación en Ciencias de la Salud del ISCIII, y a los cuales la SEDEM ha aportado su soporte científico y sus recursos humanos. Precisamente a la luz de dicho convenio surgió la idea de aprovechar los recursos del Instituto de Salud Carlos III para organizar la XVI edición del Congreso de SEDEM, dando un nuevo empuje al referido proceso aproximación de la Sociedad al mundo de la sanidad. Así pues, hemos de contemplar este XVI Congreso de la SEDEM como un nuevo fruto de esta fecunda colaboración. Desde este editorial, la Sociedad Española de Educación Médica y su Junta Directiva quieren expresar su agradecimiento y reconocimiento al Instituto de Salud Carlos III por la disponibilidad y la colaboración de todo su personal en la organización del congreso, y muy en especial a su Director, el Prof. Antonio Campos Muñoz, que siempre fue un entusiasta convencido de esta colaboración.

El lema escogido para esta ocasión y que intenta ser el denominador común del Congreso ha sido el de la Calidad en Educación Médica. La calidad en la educación en las Ciencias de la Salud es la mejor garantía para que nuestros profesionales sean competentes. Conseguir la calidad pasa, inexcusablemente, por asegurar la calidad tanto de nuestras instituciones docentes como del profesorado. Por ello el Congreso se inicia con una lección magistral a cargo de la Profa. Miriam Friedman Ben-David sobre la relación entre competencias profesionales y educación y se continua con cuatro ponencias relacionadas con el lema del congreso. Una de ellas está dedicada a la evaluación y acreditación de las Instituciones docentes. La cultura de la evaluación y de la acreditación empieza a calar fuertemente en nuestro país, como lo demuestra el establecimiento de Agencias de Evaluación de Calidad y Acreditación a nivel estatal y autonómico, siendo cada vez más las instituciones evaluadas. Por ello esta ponencia, a cargo de expertos nacionales e internacionales, discutirá los procesos de evaluación y acreditación institucional, repasando las experiencias mundiales, europeas, estatales y autonómicas, y el impacto de la evaluación en la calidad de la institución. Y todo ello tomando como referencia estándares internacionales de calidad como los elaborados por la WFME y el IIME, representado en el congreso y en esta ponencia por su director, un gran amigo de la SEDEM el Prof. A. Wojtcak.

Una segunda ponencia, a cargo de expertos nacionales, tratará los fines de la evaluación del profesorado y los procedimientos y estrategias de evaluación. Seguro que pondrán en evidencia que la evaluación objetiva de la actividad docente del profesorado no sólo es necesaria sino posible.

Una tercera ponencia estará dedicada al Tutor de Postgrado. En ésta se tratarán aspectos relacionados con la acreditación, el reconocimiento y la evaluación de los mismos y de los residentes. Finamente, la cuarta ponencia estará dedicada de forma específica a la enseñanza y aprendizaje de la Salud Pública, abordando las necesidades de formación de estos profesionales, el papel de las Escuelas de Salud Pública, y la definición del perfil profesional. Asimismo, la Conferencia Nacional de Decanos de 
Facultades de Medicina españolas tratará sobre cómo afecta el proceso de convergencia europea a las Facultades.

Además, el congreso celebrará varias sesiones temáticas dedicadas a los Contenidos, Metodología y Entornos docentes de la Medicina Familiar y Comunitaria, a la Gestión de la docencia en los hospitales universitarios y a la Biblioteca Nacional de Ciencias de la Salud. Como no podría ser de otra manera, por ser una de las actividades más importantes del congreso, dedicaremos espacio y tiempo relevantes a la presentación de comunicaciones libres en forma oral o de panel. Finalmente, también se podrá participar en los diferentes talleres programados al efecto.

Como viene siendo ya habitual desde el XIV Congreso celebrado en Lleida, las ponencias y comunicaciones aparecen publicadas en la revista Educación Médica de la cual la SEDEM es auspiciadora. Sin duda, desde que esto es así, la participación tanto en número como en calidad de las aportaciones a los congresos han aumentado de forma significativa, ya que la revista supone el primer órgano de difusión en lengua castellana de los trabajos y estudios de educación médica y de ciencias de la salud. Por ello la SEDEM reconoce y agradece el esfuerzo realizado por la Fundación Educación Médica, actual responsable de la publicación. Este año existe además otro motivo de satisfacción. Junto con el ejemplar del congreso se distribuye un suplemento especial que contiene tres documentos que consideramos han de ser muy útiles para todos los educadores. Este suplemento especial en cuya preparación han participado activamente miembros de la Sociedad, contiene por un lado dos documentos que hacen referencia a las competencias esenciales que caracterizan la profesión médica y que debiera constituir los requisitos mínimos del producto educativo de cualquier Facultad de Medicina.

Los educadores relacionados con las ciencias de la salud estamos necesitados de un lenguaje común y de un cuerpo de conceptos compartido por todos, que permita un entendimiento entre todos aquellos que trabajan en este campo científico. Por ello, el tercer documento que se presenta en al suplemento, el glosario de términos elaborado por el Institute for International Medical Education, será de gran importancia para todos los educadores. Estamos seguros de que los tres documentos que reúne este suplemento tendrán una muy buena acogida por parte de todos.

Finalizo dando la bienvenida a todos los participantes en este XVI Congreso y quiero agradecer especialmente la presencia de aquellos que han viajado desde el vecino Portugal y de aquellos que lo han hecho desde diferentes países de Américalatina. A todos os deseo que el Congreso satisfaga vuestros objetivos.

$\mathrm{Al}$ ser este mi primer congreso en el que ocupo la presidencia de SEDEM, confío que esté a la altura de los anteriores presididos por la Profa. Margarita Barón, que sigue liderando la Educación Médica desde la Presidencia de AMEE, para la que acaba de ser reelegida por tres años más. Deseo que sus éxitos en AMEE sean tantos como lo fueron en nuestra Sociedad Española de Educación Médica, y que las sociedades científicas de educación médica sigan liderando el proceso de mejora y garantía de calidad en todas la etapas del continuum de la formación médica.

Jorge Palés Argullós 
Miércoles 22 de octubre - 19,30h Aula Pittaluga

\title{
Linking Appraisal of On-the-Job Professional Competencies with Education
}

\author{
Miriam Friedman Ben-David and David Snadden, Dundee, Escocia. \\ Work Funded by the Scottish Council for Postgraduate Medical and Dental Education (SCPMDE)
}

Over the years Pre Registration House Officers (PRHOs) expressed dissatisfaction with the level of supervision, teaching and feedback they receive from their consultant supervisor (Paice et al 1997). Extensive work was done to define appropriate tasks for the pre-registration year (Stewart et al 1999), however the optimal delivery of education for the tasks identified still needs to be resolved. This situation seems to be further amplified by the workload problems within the NHS, the move to a consultant led service in the context of insufficient consultant numbers and the NEW Deal; the reduction in junior doctors hours, leading to the introduction of partial and full shifts. Within these constraints the consultant supervisors are faced with the impossible task of appraising PRHOs for their readiness to be fully registered at the end of their PRHO training. Consequently the PRHOs' education as well as their appraisal is being re-examined as a subject for national reform if seen in the wider context of change in medical education in UK. These changes address appraisal and re-validation for the whole of the medical profession in which the PRHO year may be seen as significant training period leading to the initial validation of doctors as independent practitioners. Once the PRHO is fully registered, he/she is qualified as doctors until their next validation, which in most cases occurs a few years later.

The lack of standardisation of appraisal methods, the absence of direct observations of $\mathrm{PRHO}$ performance in most programmes and undefined expected outcomes are only few of the current problems that may lead to awarding full registration to incompetent PRHOs.

Salter (1995) compared the education of pre-registration house officers in the UK with the US residency system. He concluded that the self-education of junior doctors should be maximised and posts analogous to the US "Chief Resident" could be considered including significant investment in all aspects of learning and feedback. Models of pre-registration house officers training in General Practice provide insight into valuable educational experiences such as individual training programmes, where PRHOs assume responsibilities for own patients, and having time set aside for learning. (Williams, 2001). In other countries, evaluation studies are performed to evaluate Interns mastery of important competencies. In Norway, Interns were surveyed to determine the degree of acquisition of potentially life-saving skills (Falck and Brattebo,1997). Only half of the Interns were found to acquire the skills. In Australia, differences in Interns performance due to gender, undergraduate curricula, and school of origin were investigated using a 13 competence dimension evaluation form (Rolfe et al, 1995, Rolfe et al, 1998, Pearson et al, 1998). However, these are all isolated examples of approaches to PRHO appraisal that should be considered within the global needs of the local health system.

This paper describes a PRHO appraisal model developed in Scotland, which incorporates professional and personal growth of the young doctors. The model identifies early problems with $\mathrm{PRHO}$ performance; it utilises a wide range of appraisal input. Appraisal results are translated into educational sessions, which enforce contact time with clinical tutors. A portfolio approach is employed to provide evidence, enhance PRHO progress and inform the appraisal system.
In 1999, the Scottish Council for Postgraduate Medical and Dental Education (SCPMDE), initiated a national research study to pave the way for a long awaited educational reform in PRHO training in Scotland. Curriculum changes as well as innovative approaches to PRHO appraisal comprised the main components of this nation-wide project. The four Postgraduate regional offices in Scotland are collaborating on the various aspects of the projects' research activities.

\section{Background}

In August 1998, standard documentation for PRHO performance appraisal was introduced in the form of a Record of Progress and Assessment booklet. The current Scottish system of Record of Progress and Assessment signifies the first step in the desired direction of standardising the PRHO appraisal forms, the introduction of uniformed national requirements for PRHOs for obtaining full registration and the enforcement of face to face periodical appraisal sessions of PRHOs and their educational consultant. However, the need to define the key competencies to be achieved in the PRHO year, the dissatisfaction with the box ticking exercise in completing the forms as well as the problems in securing the appraisal sessions are only a few of the concerns regarding the Record of Progress and Assessment. There was also a general feeling that the current system does not identify adequately the incompetent $\mathrm{PRHO}$, and the trail of documentation is not sufficient to stop incompetent Junior Doctors from obtaining full registration.

\section{The PRHO Appraisal Model}

The aim of this study was to develop a comprehensive systematic and standardised National PRHO appraisal system, which will outline the competencies and behaviours to be appraised as well as develop progression benchmarks and link appraisal to education.

The initial data gathering of the appraisal project concentrated on four main areas:

1. Identify the current problems in PRHO appraisal

2. Explore the key competencies to be appraised

3. Identify progression benchmarks, which highlight PRHO professional and personal growth

4. Develop an appraisal model linked to PRHOs' "on the job" education

\section{Methods}

\section{Focus Groups}

During the period Nov 1999-2001, focus Groups were conducted with PRHOs (4 sessions), Educational consultants (2 sessions), Specialist Registrars (2 sessions), Nurses (2 sessions), SHOs (2 sessions); in the North Eastern and Eastern region in Scotland. Focus group members were encouraged to discuss what works and what does not work in the current PRHO appraisal system.

The Scottish Doctor 12 Learning Outcomes based on the university of Dundee Medical School model (Harden, 1999) was presented to focus group members as a framework to stimulate the group discussion. Group members were probed to indicate critical behaviours, which separate the competent PRHO from the incompetent. The 
question of who knows the PRHO was explored in depth. Group members were asked to reflect on behaviours they felt the PRHOs are showing progress during their year of training. Qualitative analysis generated information on the above study areas.

\section{Interviews}

The Educational Development Unit at the CENTRE FOR Medical Education in Dundee, a unit of SCPMDE, currently coordinates a national consensus study for the development of learning outcomes for the PRHO year. One of the methods employed in this study was an interview with 40 randomly selected PRHOs -10 from each of the four Scottish regions. The semi-structured interviews were designed to elicit new information relative to the 12 undergraduate learning outcomes incorporating the Junior Doctors' perception. A qualitative analysis using ethnographic software generated information regarding PRHOs' important competencies, thus transforming the learning outcome model from undergraduate to the postgraduate $\mathrm{PRHO}$ year. $\mathrm{PRHO}$ narratives described the new PRHO competence behaviours under each of the 12 outcomes. The PRHOs narratives included examples of progress or improvement in skills, over the year of PRHO training. It should be noted that PRHOs were not asked during the interviews to reflect on progress, but rather information about progress was available as PRHOs reflected on their experiences.

\section{Results}

Three sets of data were obtained from the Focus Groups and the Interviews combined:

a) Current Problems: fied:

The following lists highlights of the current problems identi-

1. Lack of behavioural definitions and manifestation of clinical competencies

2. No early detection of poor performers

3. No adequate objective documentation which withstands litigation

4. No sufficient tools to separate the incompetent PRHOs from the competent PRHO.

5. Educational system does not target professional and personal growth.

6. No opportunities for feedback and tailored interventions.

7. Role of educational supervisor is not well defined.

8 . The need to identify educational support to meet the challenge of PRHO training.

b) Key competencies to be appraised

Grouped under the 12 Learning Outcomes, a list of 52 key appraisal behaviours were identified (Table 1), which focus group

\section{Table 1. PRHO Critical behaviours organised by 12-outcome mode}

A1. Clinical skills

Recognises significant signs and symptoms in

A 1.1 History in wide range of contexts

A1.2 Physical examination

A1.3 Appropriate differential diagnosis that indicates good basic and clinical science knowledge

A1.4 Usually, suggests a differential diagnosis after checking patient

A1.5 Presents accurate and complete patient findings

A2. Practical procedures

A2.1 Manages well simple procedures starting an IV, inserting a catheter, good practical skills)

A3. Investigating a patient

A3.1 Appropriate selection of tests

A3.2 Anticipate what information is needed

A3.3 Appropriate use of investigation services

A3.4 Appropriate completion of investigation forms

A3.5 Good interpretation of test results

A4. Patient management

A4.1 Correct initial management for common conditions

A4.2 Management plan is based on correct interpretation of labs and investigation results

A4.3 Good prescribing skills of drugs and dosages

A4.4 Appropriate use of multi-disciplinary team (including physiotherapy, occupational, social services)

A4.5 Knows correct treatment for common medical and surgical emergencies

A5. Health promotion and disease prevention

A5.1 Considers health promotion

A5.2 Considers disease prevention

A6. Communication

A6.1 Demonstrates good presentation skills

Effective oral \& written communication with:

A6.2.1 Nurses

A6.2.2 Peers

A6.2.3 Team members

A6.2.4 Difficult patients

A6.2.5 Patients and families

A6.3 Good command of English language

A7. Handling and retrieval of information

A7.1 Meticulous in keeping patient notes accurate, legible and up to date
A7.2 Knows how to access electronic information

A8. Understanding of basic and clinical sciences

A8.1 Confident in knowledge of clinical medicine (reads up on patients)

A8.2 Confident in knowledge of basic science

A8.3 PRHO is interested in the underlying reasons of the disease

A8.4 Seeks learning opportunities

A9. Appropriate attitudes, ethical stance and legal responsibilities

A9.1 Respects patients privacy

A9.2 Makes sure patient understands illness and treatment

A9.3 Maintains confidentiality

A9.4 Keen to make the patient better

A10. Appropriate decision making.

A10.1 Good medical judgement appropriate for this level

A11. An understanding of the doctor's role in the health service

A 11.1 Treats members of the multi-disciplinary team with courtesy (even when authority is not present)

A1 1.2 Willingness to help medical colleagues

A12. Personal development

A12.1 Seeks help appropriately

A12.2 Reliable in managing the patient (will alert supervisor on abnormal results)

A12.3 Continuously checks patients (even when authority is not around)

A12.4 Demonstrates professional curiosity

A12.5 Adjusts to working protocols

A12 6 Constructive attitude to own mistakes

A12.7 Admits mistakes

A12.8 Blames others

A12.9 Seeks feedback

A12.10 Defensive when feedback is provided

Presents the following behaviours:

A12.11.1 Arrogance

A12.11.2 Rudeness

A12.11.3 Laziness

A12.12 Handles stress well

A12.13 Accessible and available

A12.14 Appropriate attendance

A12.15 Punctuality

A12.16 Remains calm in clinical situations

A12.17 Prioritises duties in appropriate time frame 


\begin{tabular}{|c|c|}
\hline Primary areas & Secondary areas \\
\hline $\begin{array}{l}\text { Clinical Skills } \\
\text { Patient Management } \\
\text { Communication } \\
\text { Practical Procedures } \\
\text { Investigation } \\
\text { Decision Making } \\
\text { Team Work } \\
\text { Ethical and Legal Considerations }\end{array}$ & $\begin{array}{l}\text { None } \\
\text { Recognising sick people } \\
\text { Approach to patients } \\
\text { Handling responsibility } \\
\text { Organisation } \\
\text { Gaining confidence } \\
\text { Feeling more useful } \\
\text { None }\end{array}$ \\
\hline \multicolumn{2}{|c|}{ Table 3. The link between Primary and Secondary Competence Dimensions and the GMC "Good Medical Practice" } \\
\hline Good Medical Practice & Competence Dimensions \\
\hline $\begin{array}{l}\text { 1. Good Clinical Care } \\
\text { 2. Treatment in Emergencias } \\
\text { 3. Maintaining Good Medical Practice } \\
\text { 4. Teaching and Training } \\
\text { 5. Maintaining Trust } \\
\text { 6. Working with Colleagues } \\
\text { 7. Probity } \\
\text { 8. Health }\end{array}$ & $\begin{array}{l}\text { Clinical Skills, Patient Management, Investigation, Decision Making, Practical } \\
\text { Procedures } \\
\text { Recognising Sick People } \\
\text { Gaining Confidence, Handling Responsibility, Organisation, Decision Making } \\
\text { NOT APPLICABLE } \\
\text { Ethical and Legal Consideration, Approach to Patients } \\
\text { Communication, Team Work, Feeling More Useful } \\
\text { Observations using the } 360^{\circ} \text { Appraisal }\end{array}$ \\
\hline
\end{tabular}

members regarded as critical for separating the competent PRHOs from the incompetent.

\section{c) Progression Benchmarks}

Eight primary competence dimensions and 6 associated secondary dimensions were identified as areas in which professional and personal progress is evident (Table 2). Each primary and secondary dimension included a set of benchmark behaviours, which describes the scope of progression over the PRHO year.

Table 3 demonstrates the link between the Primary and Secondary Competence Dimensions identified in the PRHO year for appraisal purposes and the dimensions presented in the GMC "Good Medical Practice". The more advanced the Postgraduate training, the closer the link to the GMC "Good Medical Practice". For example, during the PRHO year, less emphasis is given to PRHOs' skills in teaching. Probity as well as Working with Colleagues are in early developmental phase.

\section{The PRHO Appraisal Model}

The proposed appraisal model responds to the study findings incorporating the key elements of appraisal and education. In the first six months, upon entering the first post, all PRHOs are appraised by employing a 52 item $360^{\circ}$ evaluation form. The forms are completed by a Nurse, SHO, Specialist Registrar and a Consultant. The $360^{\circ}$ evaluation marks are entered into a computerised database. The computer generates a summary of results from all four appraisers per PRHO. A computer diagnostic profile summarises competencies and behaviours, which were flagged. Flagging behaviour implies a mark of 5 or lower on a 19 point scale. PRHOs who obtained satisfactory $360^{\circ}$ appraisal with minimal flagging will proceed to a regular track; those who obtained a flagged profile will proceed to a diagnostic track.

The primary and secondary competence dimensions summarised in the diagnostic profile constitute the "menu" for selecting a 20-minute educational session for the regular and the diagnostic tracks. The Educational sessions follow a portfolio format in which the PRHO prepares evidence in writing with relation to a selected competence dimension. A consultant or registrar review the evidence with the PRHO according to a template and discuss the progression benchmarks assigned to this session, which are used as evaluation for the session. At the end of the educational session, the appraiser fills up the evaluation form for this session and both appraiser and appraisee sign the form. Recommendations are made by the appraiser for future work or remediation. In each subsequent educational session previous recommendation are examined. In the first 6 months, a regular track PRHO attends 3 core educational sessions. However, PRHOs with a flagged diagnostic profile will attend additional educational sessions according to the competence dimensions identified as deficient.

At the end of the first 6 months, based on the PRHO's documentation, the Postgraduate Dean will approve PRHO continuation of the programme or as pending further review. It is possible that a PRHO who started a regular track will be identified during the educational sessions as needing diagnostic sessions and vice versa. During the subsequent 6 months, the same process will be repeated.

Upon completion of the PRHO year, the documentation trail will supply ample evidence to the Postgraduate Dean, as to whether the PRHO should proceed to full-registration or is not fit for practice.

The regular track documentation trail will include two $360^{\circ}$ diagnostic profiles and six evaluations of Educational Sessions. The Diagnostic track documentation will include the above information plus evaluations from the additional Diagnostic educational sessions.

Since February 2001, 2 pre-pilot studies were conducted in 5 hospitals in Scotland in which the $360^{\circ}$ Instrument was administered and educational sessions were observed. Future pilot studies are planned if the PRHO appraisal model will be implemented in Scotland.

\section{Summary}

The proposed PRHO appraisal system links appraisal to education. Multiple appraisers' inputs ensure a global picture of PRHO performance. PRHOs are appraised using on-the-job authentic behaviours. Expected outcomes are communicated to PRHOs on entry and diagnostic reports are associated with those outcomes. Consequently PRHOs obtain early feedback on potential problems as well as on adequate performance. A portfolio approach (Friedman, 2001, Snadden, 1999) further links education and appraisal. PRHOs present evidence of achieving expected outcomes by using examples "in context". They discuss their work, reflect on their own interpretation, The appraisers use the evidence to identify the progression level on which the PRHO operates. Progression benchmarks assist both PRHO and appraiser to discuss their current level of performance. The appraiser may initiate all other forms of follow up as long as they are documented. PRHOs who participated in an educational session made the following remarks:

"It is the first time I felt like I am treated as a true professional."

"The educational sessions enforce protected time and the educational load is distributed among a number of clinical tutors. The $P R H O$ is responsible to co-ordinate the required sessions and to 
ensure that at the end of 6 and 12 months of the program, their personal PRHO file contains all required documentation for proceeding to full registration.”

\section{References}

1. Falck G. and Brattebo G., Skills of Pre-registration House Officers: gender differences reported in Norway. Medical Education, 31, 1997

2. Friedman Ben-David M., Davis M.H., Harden R.M., Howie P.W., Ker J., Pippard M.J., Portfolios as a method of student assessment, AMEE Guide No. 24, 2001

3. Harden R.M., Crosby J.R., Davis M.H., Friedman Ben-David M. Outcome-based Education from competency to meta-competency: a model for specification of learning outcomes, Medical Teacher, Vol. 21, No.6, 1999

4. Paice E., Moss F., West G., Grant G., Association of Use of a Log Book and Experience as a Pre-registration House Officer: Interview Survey, BMJ, January, 1997

5. Pearson S., Rolfe I.E., Henry R.L., The Relationship between assess- ment measures at Newcastle Medical School (Australia) and performance ratings during internship, Medical Education, 1998

6. Rolfe I.E., Andren J.M., Pearson S., Hensley M.J., Gordon J.J, Clinical Competence of Interns, Medical Education, 1995

7. Rolfe I.E., Pearson S., Fardell S.D., Kay F.J., Monitoring the Performance of Junior Doctors in the First Two Years of Postgraduate Training, Education for Health, Vol. 11, No.2, 1998

8. Salter R., The US Residency Programme - Lessons for pre-registration house officer education in the UK?, Postgraduate Medical Journal, Vol 71 (835), 1995

9. Snadden D. Portfolios - attempting to measure the unmeasureable? Medical Education 1999;33478-9

10. Stewart J., O'Halloran C., Harrigan P., Spencer J.A., Barton J.R., Singleton S.J., Identifying appropriate tasks for the pre-registration year: modified Delphi technique. BMJ, July 1999

11. Williams C., Cantillon P., Cochrane M., The clinical and educational experiences of pre-Registration house officers in general practice, Medical Education, Vol. 35(8), 2001 


\title{
Jueves 23 de octubre - 09.00 horas
}

\author{
Aula Pittaluga
}

\section{Acreditación y reconocimiento de los tutores. Incentivación de la acción tutorial}

\author{
Amando Martín Zurro \\ Red de Comisiones de Docencia de Catalunya
}

Recentrar la vertiente docente en los centros sanitarios implica avanzar hacia una mayor profesionalización de la docencia y dotarla de un rigor y reconocimiento de los que carece en la actualidad. Las actividades docentes se tienen que ir incorporando dentro de los objetivos mensurables de los que tendrán que rendir cuenta los distintos centros y servicios acreditados para la docencia.

Es demasiado habitual en nuestro sistema sanitario el papel marginal de la docencia dentro de unos centros en los que la asistencia, y en menor medida la investigación, adquieren un máximo de protagonismo y dejan desequilibrada la, en teoría, reconocida y necesaria tríada de asistencia, investigación y docencia.

Uno de los pilares que nos debe permitir modificar en profundidad esta situación lo constituye sin duda la acreditación docente que se debe plantear en tres ámbitos:

1. La acreditación de los programas docentes de cada especialidad

2. La acreditación de los centros donde se van a ejecutar los mencionados programas

3. La acreditación de los docentes y muy especialmente de los tutores

La figura del tutor dentro nuestra formación especializada es reconocida por la Orden Ministerial de junio de 1995. En dicha orden se describen algunas de las funciones que tendrá que cumplir el tutor y poco más. No hay referencias acerca del reconocimiento de que gozará el tutor, ni acerca de los recursos de que contará para cumplir con su misión, por citar algunas lagunas importantes a nuestro parecer.

La figura del tutor existe en la mayoría de los países, aunque a veces con otro nombre como "supervisor" o "mentor" y tiene una misión especifica dentro del proceso de formación de los residentes, misión que va mas allá de la docencia directa para centrarse en un papel de supervisión y guía durante todo el proceso de aprendizaje.

Sirva esto para dejar fijada la diferencia entre el tutor y el facultativo responsable de docencia que durante un periodo mas o menos largo tiene a su cargo la formación de uno o más residentes.

La ya mencionada profesionalización tiene su aplicación a la figura del tutor y se puede plasmar en los siguientes aspectos:

1) Definir el perfil del tutor y los criterios para su acreditación

2) Rigor en la acción docente y formación metodológica

3) Evaluación de la acción tutorial. Reacreditación

4) Reconocimiento efectivo del tutor

\section{1) Perfil del tutor y criterios para su acreditación:}

El tutor es una figura clave en el proceso de aprendizaje de los médicos especialistas en formación, actúa como referente y modelo y, por tanto, ha de reunir una serie de características que garanticen que desarrollará con eficacia sus funciones. Además de los requisitos profesionales y académicos es preciso que el tutor tenga unas condiciones humanas en las que resalte la capacidad de relación y comunicación con los pacientes y su entorno así como con los profesionales del centro. También es muy importante que tenga un grado suficiente de motivación y de disponibilidad para las tareas de la tutoría, con especial énfasis en las actividades docentes.

Algunas de las siguientes características constituyen elementos a considerar dentro del perfil de un tutor:

- Especialista en el ámbito de tutorización

- Profesional de plantilla de la institución

- Con suficiente experiencia

- Motivado por los aspectos docentes y de investigación

- Con capacidad para las relaciones personales

- Con buena capacidad organizativa

- Habituado al manejo de bibliografía y con publicaciones en su haber

Por lo que respecta a los criterios de acreditación se agruparían en tres bloques:

A)Criterios acordes al perfil clínico: que permita determinar un nivel de competencia clínica adecuado del tutor.

B)Criterios acordes al perfil docente: que garanticen la idoneidad docente del tutor.

C)Criterios acordes al perfil investigador: que han establecer unos mínimos por lo que respecta a actividad investigadora del tutor.

2) Rigor en la acción docente y formación metodológica:

El objetivo es que el tutor aplique a la docencia el mismo nivel de rigor científico que esta aplicando a sus tareas asistenciales. Para ello es fundamental que el tutor se forme en aspectos básicos de metodología docente.

\section{3) Evaluación de la acción tutorial. Reacreditación}

La acreditación inicial debe ir seguida de una reacreditación al termino de un periodo que proponemos sea igual que el de la especialidad.

En dicha reacreditación aparte de volver a valorar algunos de los criterios que se tuvieron en cuenta para la acreditación inicial se deberá tener en cuenta la evaluación que los residentes han hecho del tutor así como el grado de cumplimiento de la tutorización activa continuada, entendida ésta como una estrategia de implicación permanente del tutor en la supervisión directa de la formación del residente, analizando con él los aspectos problemáticos de su formación e introduciendo los cambios necesarios para optimizar el cumplimiento de los objetivos de aprendizaje; todo ello en un contexto de tutorización centrado en los intereses y necesidades del que aprende y apoyado en un potente "feedback" tutor-residente.

La percepción por el tutor de un incentivo material debería ir asociada a una evaluación anual de su actividad y al consiguiente análisis del grado de cumplimiento de los objetivos previamente definidos.

En los procesos de acreditación distinguimos dos fases principales:

- Acreditación

- Reacreditación

Estos procesos deberían integrar dos componentes:

Interno

A realizar en el propio centro o institución en que trabaja el profesional. Este componente es responsabilidad del Comité de Acreditación y Evaluación de las Comisiones de Docencia y Asesoras

Externo

A realizar por la institución que proporcionará el certificado 
oficial acreditativo de la condición de tutor en activo. En esta institución se constituirá un Comité de Credenciales encargado de juzgar los méritos aportados por cada aspirante.

La acreditación se realiza con base en tres grupos de criterios:

A) Requisitos previos

Título de especialista (excepto en el caso del Tutor de Medicina de Familia y Comunitaria).

Médico de plantilla (se podría nombrar tutor un médico interino cuando las circunstancias lo hiciesen necesario y siempre con el correspondiente informe justificativo del Jefe de Estudios o Coordinador de la Unidad Docente de Medicina de Familia y Comunitaria).

Experiencia en el centro: dos años.

\section{B) Informes personales}

Favorables del Jefe de Servicio o Departamento i del Jefe de Estudios o Coordinador de la Unidad Docente de Medicina de Familia y Comunitaria.

C) Créditos curriculares (adquiridos en los 3-5 años previos)

Actividades formativas en aspectos relacionados con metodología docente.

Experiencia como docente (universitario o no).

Publicaciones y comunicaciones científicas.

Líneas de investigación. Becas. Premios.

Cumplimiento del perfil del tutor.

La duración de la acreditación será igual a la del programa de la especialidad correspondiente.

La acreditación es firmada por el gerente del centro a propuesta de la Comisión de Docencia o Asesora.

La retirada de la acreditación se ejecuta por el gerente del centro a propuesta de la Comisión de Docéncia o Asesora.

La reacreditación se basa en los mismos criterios curriculares que la acreditación añadiendo los siguientes:

- Cumplimiento de los criterios de tutoritzación activa continua.

- Evaluaciones de los residentes.

\section{4) Reconocimiento efectivo del tutor:}

Los procesos de acreditación y reacreditación de los tutores solamente serán posibles y eficaces cuando la oportunidad de ser nombrado como tal tenga los suficientes elementos de incentivación y atractivo personal y profesional para generar un cierto grado de competencia para acceder a esta situación.

Este es un elemento primordial y condición indispensable para poder implementar un sistema de acreditación de tutores. No se puede exigir mas rigor ni pedir cuentas a los tutores acerca de su actividad docente sino están adecuadamente reconocidos e incentivados.

La acreditación y reacreditación formal de nuestros tutores de postgrado,en un contexto de reconocimiento suficiente y efectivo de su labor ha de incidir de forma clara sobre la motivación profesional y la calidad de los procesos de atención. Por otro lado, la falta a de homogeneidad de este reconocimiento entre atención primaria y hospitalaria nos sitúa en un marco poco coherente des de la perspectiva de sistema sanitario.

Los ámbitos principales del reconocimiento explícito de la acción tutorial serían los siguientes:

Documental: mediante certificados oficiales del propio centro y de otras instituciones de ámbito estatal o autonómico.

Disminución de la actividad asistencial, que permita disponer de un numero de horas suficiente para la tutoría.

Económico, como parte de la retribución variable establecida por la consecución de objetivos

Formativo, facilitando y priorizando la participación de los tutores en actividades docentes especialmente de tipo metodológico.

Carrera profesional, valorando adecuadamente el merito de la propia tutoría en el contexto de la promoción en el seno de la empresa y del centro.

\section{Sistemas de evaluación de los residentes. Rol del tutor en los mismos.}

\author{
Juan D. Tutosaus.
}

\section{REDECA}

Los sistemas de evaluación se pueden clasificar básicamente en dos tipos: los certificativos o sumativos y los formativos o continuados. Ambos son pilares fundamentales sobre los que se debe asentar una docencia de calidad, dado que sin ellos no podemos saber el resultado de las actuaciones formativas ni por tanto modificarlas.

La evaluación sumativa se hace al final del aprendizaje y su fin es acreditar requisitos de titulación o de capacitación profesional. Trata de medir el nivel de formación alcanzado y si alcanza el nivel considerado como óptimo, al final del período formativo, lo que se puede realizar con un examen final o con una prueba de evaluación de la competencia (ECOE). La evaluación formativa, continuada, se hace durante el proceso de aprendizaje y su fin es mejorar el mismo facilitando la adquisición de conocimientos y actitudes y mejorando estas.

En España el sistema MIR viene regulado por la Orden Ministerial de 1995 en la que se contempla cómo se ha de evaluar a los residentes. La evaluación a la que hace referencia es prácticamente formativa, aunque con peculiaridades que la hacen incompleta; por otro lado, la orden casi no hace alusión al sistema de evaluación sumativa por el que se podría considerar a un residente como no apto. Todo esto ha sido uno de los temas principales de las reuniones de Comisiones de Docencia regionales celebradas este mismo año en Cádiz y Barcelona (mayo) y en la nacional de Madrid (18 de junio).

En Europa, la normativa está regulada desde 1986 por el llamado Advisory Commitee on Medical Training (ACMT); en su informe de 1996 explicitó que: "Es improbable que todas las habilidades y conocimientos requeridos para un especialista puedan ser calificados solamente mediante un examen (evaluación sumativa). es preferible que la valoración de la capacidad del residente se haga de manera continuada durante todo su periódo formativo (evaluación formativa)".

El ACMT recomienda para la formación de residentes un sistema evaluativo ecléctico que incluya entrevistas personalizadas tutor-residente (feed-back o similares) y documentos instrumentales orientadores, como el "Libro del Residente" (que permita, tanto al Residente como al Tutor, guiarse en los objetivos y etapas a cumplir), las fichas de rotación y anuales e incluso exámenes convencionales para detectar objetivos determinados (por ejemplo, los programas teóricos de las distintas especialidades).

El tutor se debe implicar en el proceso de la evaluación reflexionando permanentemente y sumergiéndose en una cultura profesional de la docencia en general y de su evaluación en particular, una cultura centrada en el residente y en la evaluación como elemento primordial de mejora de la calidad profesional prestada. Al ejercitar el tutor su papel, debería tener en cuenta que la ACMT recomienda que a su vez el mismo debe estar cualificado y con un determinado grado de formación como formador.

José Ma ${ }^{a}$. Martín Moreno, hoy Director General de Salud Pública, presentó hace ahora unos diez años una ponencia sobre evaluación de la investigación en este mismo lugar; entonces el estaba en el Consejo Científico del FIS y en el de la Comisión Europea; en su ponencia mostró un chiste al respecto, muy celebrado, protagonizado por wikingos que arrojaban aceite hirviendo desde las almenas y matacanes de un castillo. Uno le preguntaba al otro acerca de porqué creía que estaban haciendo eso; el otro le respondía: ¡Porque en el fondo nos gusta! También aquí, este gusto por la evaluación docente en particular y por la docencia en general, es la principal motivación con la que deben contar nuestros tutores.

En la Orden Ministerial española referida se exponen buena parte de las funciones del tutor y de las funciones específicas res- 
pecto a la evaluación. Asimismo se regula la composición de los comités de evaluación. Por tanto, el papel del tutor en la evaluación se debe situar dentro de las funciones generales del mismo, como pueden ver en el cuadro 1 .

\section{Cuadro 1}

\section{FUNCIONES DE LOS TUTORES}

1. Asegurar que el MIR cumpla sus objetivos.

2. Desarrollar y utilizar habilidades pedagógicas.

3. Identificar dificultades y tratarlas.

4. Proponer los planes individuales de formación.

5. Supervisar la realización de los programas.

6. Fomentar la participación en actividades docentes e investigadoras.

7. EVALUAR A LOS MIR.

8. Elaborar la Memoria anual de su especialidad.

La función de evaluación de los tutores aquí expresada está íntimamente relacionada con el aseguramiento del cumplimiento de los objetivos del residente, ya que para ello hace falta evaluarlo. Volveremos sobre estos objetivos, ya que es preciso conocerlos adecuadamente para saber como medir si se han alcanzado. Igualmente ocurre con algunas de las demás funciones generales, como la supervisión (y monitorización, habría que añadir) de los programas docentes y la realización de las actividades docentes e investigadoras. Pero para continuar centrando el tema, nos vamos a referir a las funciones propias de la evaluación que nos menciona la norma y que pueden observar en el cuadro 2 .

\section{Cuadro 2}

\section{FUNCIONES DE LOS TUTORES SOBRE LA EVALUACIÓN}

1. Conocer los criterios a aplicar.

2. Realizar la evaluación, cumplimentando los correspondientes documentos.

3. Controlar que las actividades $(A, D, I)$ del residente se anoten en su Libro correspondiente.

4. Supervisar mensualmente las anotaciones del Libro.

5. Participar en los Comités de Evaluación.

6. Notificar la calificación al residente y a la C.D.

7. Controlar las rotaciones externas.

8. Evaluar la participación, en cursos, congresos y demás reuniones, del residente.

9. Actuación especial en caso de evaluación negativa.

10. Evaluación final de la residencia.

Aquí ya procede realizar un análisis pormenorizado de cada una de las mismas. La primera dificultad comienza con el conocimiento de estos criterios a aplicar, ya que en sí mismos no están definidos de una manera homogénea. Por tanto, cada tutor puede entenderlos de una u otra manera y aquí ya nos va a hacer falta comentar algunos de los criterios que debe tener una evaluación, recopilados en el cuadro 3 :

\section{Cuadro 3}

\section{PRINCIPIOS SOBRE LA EVALUACIÓN}
1. Ética
2. Continuada
3. Participativa
4. Corroboradora
5. Atributiva
6. Entendible
7. Diversificada
8. Catalizadora
9. Globalizadora

10. Metódica
11. Modificadora
12. Metaevaluada
13. Colegiada
14. Creíble
15. Procesal
16. Servicial
17. Basada en el conocimiento
de lo evaluado y de la enseñanza

No está nada claro que estos requisitos conceptuales se apliquen en la práctica docente diaria en nuestros hospitales y centros de salud. Deberíamos entrar a reflexionar sobre cada uno de estos aspectos pero lo obviaremos porque vamos a ajustarnos al espacio de tiempo disponible.

Aquí, en el desarrollo de la evaluación formativa es donde yo veo el rol principal del tutor en la evaluación, no limitándose (como ocurre en la realidad diaria) a ser un mero recopilador y calculador de medias aritméticas más o menos ponderadas, de las calificaciones que los compañeros a cargo del residente en sus diversas rotaciones, le han ido asignando. Debe desempeñar un papel más activo y para ello se debe valer de los distintos instrumentos que la metodología docente pone en sus manos.

En la metodología de la evaluación continuada el tutor tiene que tener muy presente la realización de entrevistas personalizadas plasmadas en informe final de excelencia (cuando proceda), la cumplimentación del libro de residentes o documento similar (admitido por los auditores oficiales de nuestro Ministerio el formato electrónico del mismo) y de las hojas de evaluación de rotación y final. El tutor debe supervisar la documentación de todas las actividades docentes (sesiones clínicas, clases, cursos), sobre todo las activas, la documentación de tipo bibliográfico sobre la actividad investigadora realizada (proyectos, comunicaciones, ponencias, tesis, publicaciones, etc.) y no debería pasar por alto la posibilidad más que recomendable de realizar exámenes parciales, como única manera de evaluar objetivamente aspectos de los programas teóricos de las especialidades.

En toda la actividad evaluadora es fundamental que se entienda que es bidireccional, debe informar al residente de los resultados y a su vez el debe estar informado sobre los aspectos que el residente considera mejorables en la unidad docente.

El tutor debe conocer, saber manejar y utilizar realmente los medios existentes de evaluación para poder llevarla a cabo, especialmente aquellos en los que su papel es de protagonista, es decir los medios que permiten realizar una adecuada evaluación formativa. Por ello debe conocer técnicas como el Feedback, el Self-audit, el Peer-review, el Rol-playing, la observación real, etc., que se explican en los cursos para tutores y de los que la normativa y los programas docentes de las distintas especialidades no dicen nada.

El cómo hacer todo esto implica reunirse continuamente con el residente y con los tutores de rotación o especialistas del servicio a cuyo cargo directo está el residente y todo esto implica estar permanentemente comunicándose. Este rol del tutor como comunicador, debe ser algo aprendido y entrenado. Buena parte de los cursos de metodología docente contienen al menos un $50 \%$ de temas acerca de teoría y practica de la comunicación. Hay que tener presente que el $85 \%$ de los motivos de las reclamaciones de los usuarios están relacionados muy directamente con déficit de comunicación.

Especial cuidado hay que tener en que el residente no entienda esta evaluación (que pretende detectar deficiencias para corregirlas) como una crítica negativa o aún peor, como una sanción. La evaluación sumativa, esa a la que en este país y en general en los países latinos nos tienen acostumbrados desde el parvulario, es algo diferente que además debería ser realizada por otros personajes docentes y no por el tutor, aunque éste pueda y deba participar en ella. En la misma proporción en que la evaluación formativa es practicada por la misma persona que la evaluación sumativa, el discente pierde confianza en su tutor.

Yo veo la evaluación sumativa centrada en una prueba tipo ECOE o similar (realizada por expertos externos) cuyos resultados deberían incorporarse como uno más dentro de un proceso (complementando la evaluación formativa) a los comités de evaluación, en los que el tutor es un participante más, aunque con información privilegiada que puede y debe usar para matizar.

El papel del tutor en la evaluación formativa debería ser de protagonista principal, teniendo poco que ver con el papel de contable y certificador que en la evaluación realiza actualmente y casi en exclusiva. Pero debe ser consciente en todo momento de que al ejercitar su papel la ACMT recomienda que a su vez el mismo debe estar cualificado y con un determinado grado de formación como formador.

Recientemente hemos realizado un estudio Delphi con un panel de expertos constituido por jefes de Unidades Docentes de elite, así como sus tutores, especialistas y residentes. En su con- 
junto hubo una clara mayoría de inclinarse por una evaluación mixta, formativa y sumativa final, con evaluadores externos esta última.

En este estudio y respecto a esta cuestión aparecieron, lógicamente, algunas diferencias según quien opinase.

En los programas de las Comisiones Nacionales de las Especialidades (CNE) deberían incluirse criterios, indicaciones y recomendaciones sobre el proceso evaluador de sus contenidos, en especial de los conocimientos teóricos y técnicos, de las habilidades prácticas y de las actitudes (dedicación, autocrítica, ética, etc.), que ayudaran al tutor en su papel evaluador. En el estudio referido, se considera que la evaluación no se sustenta lo suficiente en los Programas Docentes y que en general hay que modificar el sistema.

También debería explicitarse, como hacen algunos decanatos de medicina, que debe haber límites a las evaluaciones excelentes, como los hay a las matrículas de honor en el pregrado y como algunas especialidades (Medicina Familiar y Comunitaria) han establecido desde sus CNE. Y es que las actividades sociales tienen distribuciones típicas, con extremos de mínimas frecuencias y un centro con la mayor proporción, ‘por lo que sería coherente que en las evaluaciones de los residentes dichos extremos (el "no apto" y el "excelente") se justificaran debidamente (la ausencia de "no aptos" y el exceso de "excelentes"), aunque sepamos que la población de residentes es ya un colectivo muy seleccionado.

Resumiendo, es preciso que el tutor recupere en la evaluación de residentes el papel activo que siempre debió tener y que le reconoce la normativa vigente, pero que salvo escasísimas y honrosísimas excepciones, en la realidad no practica por falta de costumbre, de conocimientos en la materia y, sobre todo, de tiempo.

El tiempo que los docentes necesitan, para dedicarlo a su propia formación primero y para aplicar con los residentes las técnicas aprendidas, es el primer objetivo que deberíamos conseguir para disponer de una docencia profesionalizada. Y quede claro que este tiempo para la dedicación a la docencia no es ningún incentivo que algún directivo, más o menos simpatizante de la formación sanitaria, pueda graciablemente conceder. El tiempo laboral es una herramienta de trabajo imprescindible para realizar una labor de profesional. Lo contrario es un engaño.

\section{¿Es necesaria y compatible la existencia del tutor de médicos residentes dentro de nuestras estructuras asistenciales?}

\author{
Jesús Manuel Morán Barrios.
}

\author{
Unidad de Investigación y Docencia. Hospital de Cruces. \\ Baracaldo. Vizcaya
}

\section{Introducción}

Si en el momento actual un ciudadano pregunta a los responsables de las organizaciones sanitarias, o de los servicios asistenciales por la calidad del médico especialista que acaba de formarse en su organización ¿cual sería la respuesta?, ¿en qué se fundamentaría?, ¿tiene ese responsable información objetiva para afirmar que todos los médicos que se forman en su organización reúnen los criterios de competencia profesional exigibles en la sociedad actual?, ¿puede demostrarlo?, Es indudable que los centros sanitarios y los servicios desean tener médicos residentes, ¿para qué?, ¿por prestigio?, ¿por que son un elemento motivador?, ¿por qué precisan de su trabajo?. Me temo que no hay respuestas definitivas a muchas de estas preguntas. Por otra parte todos sabemos que el desarrollo en cascada del conocimiento médico, gracias al sistema MIR (Médicos Internos y Residentes), ha sido la clave del alto grado de competencia profesional alcanzado en el SNS. Las reflexiones del presente artículo giran en torno a la formación de especialistas en hospitales ya que la organización de la Medicina Familiar y Comunitaria tiene un desarrollo diferente, y de las razones para la existencia de tutores MIR y del método para resolver el desarrollo de la función tutorial.

\section{Acreditación para la docencia y responsabilidad social}

Cuando los centros y los servicios asistenciales solicitan la acreditación para la formación de especialistas se supone que lo hacen por varias posibles razones: la primera porque se creen en la obligación de dar un servicio a la sociedad, la segunda por que se sienten capaces de trasmitir los conocimientos generados en la organización, la tercera porque disponen de los recursos necesarios para asumir la responsabilidad solicitada y la cuarta porque son capaces de demostrar y garantizar a la sociedad la competencia adquirida por los profesionales formados y por tanto su titulación. Hay otras razones que reflejan una realidad diaria, entre ellas pueden estar las necesidades del funcionamiento de los centros, el interés particular de los médicos de plantilla y aspectos de prestigio del servicio. Acreditar un centro o servicio para la formación médica especializada, disponer de médicos residentes, significa por tanto, que el centro y el servicio asumen la responsabilidad delegada de la sociedad, de formar a un futuro especialista poniendo los recursos necesarios para garantizar que un recién licenciado conseguirá las competencias profesionales exigibles de una práctica profesional moderna.

\section{Estructura y organización como respuestas al compromiso de formar medicos especialistas}

Nuestro sistema de formación de médicos especialistas (Sistema MIR) tiene dos niveles, por un lado está el central o planificador-acreditador ( $\mathrm{M}^{\mathrm{o}}$ de Sanidad y Consumo) con competencias bien definidas y desarrolladas: El sistema de acreditación de centros y servicios, la definición de especialidades y sus programas formativos, el método de acceso y la expedición de títulos. Por otro lado el nivel operativo en los centros asistenciales: Comisión de Docencia, tutores y servicios asistenciales. El primer nivel, en general, cumple adecuadamente su misión. Sin embargo es en el segundo nivel, el operativo, donde no se han conseguido desarrollar adecuadamente las funciones docentes de un centro sanitario a pesar del gran avance que supuso la orden de Comisiones de Docencia de 22 de Junio de 1995 (BOE 155 pag 19793). Si contemplamos el hospital como tres subsistemas, el asistencial, el docente y el investigador, es el sistema docente el más desfavorecido. La asistencia es la principal misión de un centro y lógicamente los esfuerzos deben de ir dirigidos en esa dirección, la investigación ha alcanzado las cotas de reconocimiento exigibles, tiene un costo pero también genera recursos y hay una apuesta, por fin, por desarrollarla de manera ordenada en todo el SNS. Muchos centros sanitarios tienen fundaciones o institutos y solos o como organización han definido sus planes en ese sentido. Sin embargo, no se conocen datos de ningún centro sanitario español que haya realizado un plan estratégico dirigido a la formación de especialistas a pesar de que este programa tiene un alto coste directo en salarios e indirecto en el uso de recursos y no olvidemos las obligaciones adquiridas ante la sociedad al pedir que vengan a nuestro centro médicos recién licenciados.

Formar médicos especialistas supone integrar a un médico recién licenciado en las actividades asistenciales del centro con responsabilidad creciente y supervisión decreciente en el tiempo. ¿Es posible llevar a cabo esa labor formativa sin disponer de instrumentos y recursos que garanticen que esa integración está adecuadamente planificada, supervisada y que el resultado final (médico especialista) es consecuencia del cumplimiento de un programa adaptado a las demandas sociosanitarias actuales?. No se trata de aplicar al modelo MIR un sistema académico, pero entre el extremo de integrar al licenciado en la práctica asistencial informalmente, de acuerdo con la realidad del "día a día" y la planificación estricta y supervisión permanente limitativa de una libertad de acción, existe un término medio deseable 
Integrar a un MIR en el sistema asistencial y garantizar su formación con tendencia a la excelencia significa disponer de dos instrumentos: Un programa individual de acuerdo a las competencias a alcanzar y un sistema de supervisión del mismo. Un especialista del siglo XXI, en una sociedad desarrollada debe de alcanzar al menos las siguientes competencias (1): experto clínico, consejero de salud, gestor de recursos, habilidades en comunicación con el paciente y familiares, saber trabajar en equipo, gestor del conocimiento (búsqueda, integración y transmisión de conocimiento científico), y tener valores profesionales referidos a conocimiento y conducta acorde a unos principios éticos y morales de la sociedad. Alcanzar estos objetivos no parece suficiente con una simple integración funcional en la actividad asistencial del centro y dejarse llevar por la corriente de "las costumbres" de ese centro o servicio. Se precisa de un programa explícito por objetivos anuales, adaptado al centro, evaluable y flexible en función del aprendizaje del MIR (es decir, no dependiente de las necesidades asistenciales) y un responsable en el servicio que supervise y garantice el cumplimiento del programa haciéndolo compatible con la realidad asistencial. La responsabilidad de la gestión de un servicio recae en la jefatura del mismo y al igual que el reparto de tareas organizativas asistenciales por áreas temáticas o estructurales entre los mandos intermedios del servicio, la formación especializada debe de tener, en la lógica de la organización de actividades humanas, un responsable. Bajo este análisis, la figura del tutor de médicos residentes es una necesidad organizativa básica y no simplemente el cumplimiento de un formalismo. Un servicio que dispone de un tutor que realmente programa, coordina, dirige, supervisa y evalúa la progresión de un MIR, es un servicio que ha asumido con todas sus consecuencias las responsabilidades de estar acreditado para la formación médica especializada y puede demostrar a la sociedad la calidad de los especialistas que forma.

Se podría argumentar que los códigos de funcionamiento de las organizaciones de profesionales, implican una serie de mecanismos muchas veces no escritos, que implícitamente garantizan la calidad de los profesionales que pertenecen a esa organización o "club". El grupo se autogestiona a sí mismo para mantener su prestigio o su nivel de competencia. Es decir, que si el clima de un servicio es favorable a todas las tareas asistenciales, docentes e investigadoras, bajo el liderazgo de un "patrón" respetado y cualificado, el tutor sobra. Pero no todas las realidades son iguales. Cuando esos profesionales forman parte de una organización de servicio público, jerarquizada, que responde a una exigencia social como son los cuidados de la salud, es necesario que los códigos internos se expliciten y actualicen, y que la organización y sus responsables directos ante la sociedad, desarrollen instrumentos que permitan responder al ciudadano que demanda y quiere pruebas palpables, no solo opiniones. No es posible seguir formando médicos especialistas cuya competencia profesional, supuestamente adecuada a las demandas y necesidades sociales, se valore solo subjetiva e informalmente. Por tanto, nuestra organización sanitaria precisa para la formación de especialistas, una estructura y organización que se base en programas y responsables docentes cualificados.

Hasta aquí, se exponen las argumentaciones de porqué es necesaria la existencia de un tutor de la formación médica especializada en nuestras organizaciones. Tutor que por otra parte debe de tener la adecuada formación en planificación y gestión de programas docentes de profesionales y conocimiento sobre las competencias profesionales de un médico moderno.

\section{El tutor en la organización asistencial}

La figura del tutor pretende ser, al estilo inglés de enseñanza, la persona que de una manera continuada, canaliza, orienta, estimula y contrasta la adquisición de conocimientos y que finalmente garantiza ante la sociedad la competencia del futuro profesional. En resumen, es la persona más cercana al discente con la que este comparte experiencias y las supervisa. ¿Es esto compatible con nuestra realidad?. La gran mayoría de tutores conocen sus funciones, (elaboración de planes individuales de formación, supervisión directa y continuada, fomento de actividades docentes y de investigación, y evaluación continuada), sin embargo no pueden desarrollarlas por una inadecuada organización del centro y servicio, donde las responsabilidades asistenciales impiden disponer del tiempo adecuado para una programación y supervisión adecuada del MIR acorde a los objetivos programados. Los servicios y los hospitales debieran de contemplar este aspecto en sus contratos programa. El perfil y necesidades del tutor están bien descritos por J. D. Tutosaus (2) destacando la disponibilidad de tiempo, formación en metodología docente y la necesidad de concienciar a los hospitales sobre la responsabilidad adquirida en materia de docencia.

$\mathrm{Si}$ un centro hospitalario decide incluir en su misión la docencia MIR, se debe garantizar: 1) la existencia de un liderazgo al respecto desde la alta dirección y mandos intermedios (Jefe de Estudios, Jefes de Servicio), 2) que la organización dispone de una estrategia y plan docente, que involucra a todas las personas en dicho plan (tutores y plantillas) facilitando la toma de decisiones y la asunción de responsabilidades, así como facilitando la formación en función de los objetivos, 3) que se aportan los recursos necesarios (físicos, materiales, económicos y tiempo), 4) que se desarrollan los programas integrándolos en la organización asistencial de acuerdo a un perfil definido de médico especialista, a las necesidades de los MIR y se adapta a las demandas sociales de un tipo de médico y 5) la organización debería de ser capaz de medir cuantitativamente el resultado final, es decir el grado de cumplimento de los principales objetivos docentes planificados. Dentro de este esquema es donde la figura del tutor toma relevancia como gestor de un programa de especialización planificado bajo una estrategia docente general del centro. No sería necesario estar cuestionando permanentemente su reconocimiento, autoridad y organización temporal de su trabajo. Es en suma una parte fundamental del engranaje de un plan estratégico, donde la estructura docente tiene un reconocimiento orgánico y no se limita meramente a un desarrollo voluntario e informal.

El contrato programa de los centros y de los servicios donde figure las cargas que suponen el desarrollo y aplicación de los programas formativos, la supervisión de los mismos, evaluación y el tiempo de dedicación supone aceptar un compromiso con la formación. Es incuestionable la necesidad de colaboración de todo el servicio en la supervisión del programa formativo y en la adecuación del mismo a las necesidades de aprendizaje del MIR. Un método al respecto podría ser, al igual que las sesiones clínicas, las sesiones formales de tutorización para servicios grandes con gran número de residentes, donde la el tutor gestiona con la plantilla mediante un método objetivo, la evolución de cada residente.

\section{Conclusiones}

1. La acreditación de centros y servicios supone asumir la responsabilidad social de formar médicos de excelencia acorde a un perfil de competencias en función de las necesidades de una práctica clínica moderna y demostrar el grado de cumplimiento del compromiso adquirido.

2. Los centros sanitarios deben por tanto, definir una estrategia docente y planificar la formación de médicos especialistas, aportando los recursos necesarios acorde a objetivos explícitos.

3. Dentro del esquema de estrategia y planificación, la figura del tutor surge como una necesidad, como un gestor de los programas docentes de los médicos residentes de los servicios.

4. La existencia de un programa de formación individual, flexible y no condicionado por necesidades asistenciales, es el eje sobre el que debe de pivotar todas las decisiones en materia de formación del MIR

\section{Bibliografía}

1. CanMEDS 2000: Extract from the CanMEDS 2000 Project Societal Needs Working Group Report. Medical Teacher 2000; 22 (6): 549-554

2. J.D. Tutosaus, T Gómez Cía, J. Díaz Oller, I. Gómez Blázquez, S. Morales Conde y S. Morales Méndez. Perfil de los tutores de un gran hospital universitario. Educación Médica 2002; 5(1): 27-33.

\section{Agradecimientos}

A José Ignacio Pijoán por las opiniones aportadas. 